\title{
Physicians' roles on the front line of climate change
}

\author{
Barbara Sibbald BJ
}

$\mathrm{T}$ he Intergovernmental Panel on Climate Change (IPCC), made up of more than 2000 of the world's leading scientific experts, has concluded that the build-up of carbon dioxide is accentuating the greenhouse effect, trapping heat and increasing global warming and climate change. ${ }^{1}$ Although some people deny that human activity is of any consequence, the scientific evidence that global warming is happening and causing harm is incontrovertible. In addition, climate change is having an adverse effect on human health - and it is bound to worsen. ${ }^{2}$

The United Nation's new Atlas of Health and Climate, the result of a unique collaboration between the World Health Organization (WHO) and the World Meteorological Organization, connects the scientific dots between health, climate and climate change. ${ }^{3}$ The incidence of dengue is increasing, as are cases of West Nile virus and bacterial illnesses such as cholera and salmonellosis. ${ }^{4}$ Reports of extreme weather events have more than tripled since the 1960s, leading to injury, disruption of medical services, shortages of food and water, and diarrheal diseases. ${ }^{3}$ By the 2050s, heat events that once occurred every 2 decades are expected to occur, on average, every $2-5$ years. ${ }^{3}$ Drought is becoming more widespread. Longer growing seasons mean more natural allergens, and more carbon dioxide means an increase in pollen; rates of asthma and respiratory issues will increase.

The IPCC acknowledges that climate change may bring some health benefits, such as fewer deaths from exposure to cold and less mosquito-borne disease in new drought zones; however, scientists expect such benefits will be far outweighed by negative effects on health.

Since the 1970s, climate change has caused more than 140000 deaths per year; by 2030, the direct cost to health is expected to be between US $\$ 2$ and US $\$ 4$ billion per year. ${ }^{5}$ We would not be the first to say that this may be the foremost public health issue of our era.

Physicians will be among the front-line responders to the dire effects of climate change, from malnutrition, to increases in vector-borne disease, to respiratory illness and the aftermath of traumatic weather events. Thus, should physicians not be at the front line of efforts to mitigate climate change now? Physicians can make a difference at the political, professional and person levels.

Politically, not enough is being done. Delegates to the recent 2012 United Nations climate change conference in Doha, Qatar, agreed to extend the 1997 Kyoto protocol; however, some countries, including Canada, have opted out, and the United States never opted in.

Physicians have political clout. In addition to lobbying nationally, Canadian physicians can lend their credibility to a growing international movement. The December 2012 Doha Declaration on Climate, Health and Wellbeing ${ }^{2}$ calls for an accounting of the health impacts of climate change; rapid and increased investment in climate mitigation and adaptation (including more funding for clean, renewable energy); and inclusion of the health sector in climate action. It also points out that reducing greenhouse gases holds the promise of health benefits worldwide, such as improved air quality and increased exercise through biking and walking.

"Human health is profoundly threatened by our global failure to halt emissions growth and curb climate change," states the declaration. Included in the 86 organization signatories to the Doha Declaration are the World Medical Association and International Council of Nurses, 2 UK medical colleges, medical associations in South Africa, Norway, New Zealand and Russia, and the Canadian Nurses Association. Should not Canadian medical bodies sign too? At the very least, Canadian physicians can join the 1200 individual signatories to this declaration; its specific health-related actions are comprehensive, sensible, timely and evidence-based.

Physicians can also act on a professional level. For example, physicians who decide how their hospitals handle anesthetic gases or how health centres and offices dispose of clinical waste have a direct impact on greenhouse gas emissions. ${ }^{6}$

The time of warnings and cautions is over. We are headed on a disastrous trajectory that only immediate, wise action can mitigate. If we do not act now, our descendants will bear the consequences, and we will bear the blame.

\section{References}

1. Intergovernmental Panel on Climate Change. Climate change 2007: synthesis report. 2007. Geneva (Switzerland): The Panel; 2007. Available: www.ipcc.ch/pdf /assessment-report/ar4/syr/ar4_syr.pdf (accessed 2013 Jan. 15).

2. Doha Declaration on climate, health and wellbeing: health must be central to climate action. Available: http://dohadeclaration.weebly.com/index.html (accessed 2013 Jan. 15).

3. World Health Organization, World Meteorological Organization. Atlas of health and climate. Geneva (Switzerland): The Organizations; 2012. Available: www.who.int /iris/bitstream/10665/76224/5/9789241564526_eng.pdf (accessed 2013 Jan. 15).

4. Cooney CM. Climate change and infectious disease: Is the future here? Environ Health Perspect 2011;119:a394-7. Available: www.ncbi.nlm.nih.gov/pmc/articles /PMC3230419/ (accessed 2013 Jan. 15)

5. World Health Organization. Climate change and health. Geneva (Switzerland): The Organization; 2012. Available: www.who.int/mediacentre/factsheets/fs266/en /index.html (accessed 2013 Jan. 15).

6. Kagoma Y. Stall N, Rubinstein E, et al. People, planet and profits: the case for greening operating rooms. CMAJ 2012;184:1905-11.

Competing interests: See www.cmaj.ca/site/misc/cmaj_staff.xhtml

Affiliation: Barbara Sibbald is Deputy Editor, Analysis and Humanities, CMAJ.

Correspondence to: $C M A J$ editor,pubs@cmaj.ca

CMAJ 2013. DOI:10.1503/cmaj.130087 